\title{
STRATEGI THINK PAIR SHARE UNTUK MENINGKATKAN AKTIVITAS BELAJAR PADA MATA PELAJARAN ILMU PENGETAHUAN ALAM
}

\author{
Lidia, Mansur, Ricka Tesi Muskania* \\ Program Studi Pendidikan Guru Madrasah Ibtidayyah, \\ Institute Agama Islam Negeri Pontianak, Indonesia
}

Korespondensi. E-mail: ricka.muskania@gmail.com

\begin{abstract}
Abstrak
Tujuan penelitian ini untuk meningkatkan aktivitas belajar peserta didik kelas IV pada mata pelajaran Ilmu Pengetahuan Alam menggunakan strategi Think Pair Share. Penelitian ini bagian dari penelitian tindakan kelas (PTK) dengan dua siklus, setiap siklus terdiri dari empat tahap, yaitu perencanaan, pelaksanaan, observasi dan refleksi. Lokasi penelitian adalah SD Negeri 09 Pontianak Timur Tahun Pelajaran 2017/2018 peserta didik kelas IV. Teknik pengumpul yang digunakan adalah observasi dan dokumentasi dengan instrumen panduan observasi dan checklist dokumen. Hasil penelitian menyimpulkan bahwa dengan menggunakan strategi Think Pair Share peningkatan aktivitas belajar peserta didik diperoleh data sebagai berikut: Prasiklus sebesar 58,30\%, siklus I mengalami peningkatan sebesar 8,24\% menjadi $66,54 \%$ dan siklus II mengalami peningkatan sebesar 9,19\% menjadi 75,73\%.
\end{abstract}

Kata Kunci: Strategi Think Pair Share, Aktivitas Belajar.

\section{THINK PAIR SHARE STRATEGY TO IMPROVE LEARNING ACTIVITIES IN NATURAL SCIENCES LESSONS}

\begin{abstract}
This study aims to improve the learning activities of fourth grade students in Natural Sciences subjects using Think Pair Share strategies. This research is a classroom action research $(C A R)$ which is carried out in two cycles, each cycle consists of four stages, namely planning, implementation, observation and reflection. The research location is SD Negeri 09 Pontianak Timur Academic Year 2017/2018 for students in grade IV. Data collection techniques used are observation and documentation with observation guide instruments and document checklists. The results concluded that by using the Think Pair Share strategy, the increase in learning activities of students was obtained as follows: Pre-cycle of 58.30\%, cycle I had an increase of $8.24 \%$ to $66.54 \%$ and cycle II had an increase of $9.19 \%$ to $75.73 \%$.
\end{abstract}

Keywords: Think Pair Share Strategy, Learning Activities.

Copyright (2018, JRPD, ISSN 2615 - 1723 (Print), ISSN 2615 - 1766 (Online) 


\section{PENDAHULUAN}

Pendidikan di sekolah dasar merupakan dasar untuk jenjang pendidikan menengah, sehingga tanggung jawab para pendidik di sekolah dasar sangat besar bagi terlaksana-nya pembelajaran yang bermakna, agar para peserta didik dapat memnuhi tujuan pembelajaran yang ditetapkan.

Pendidikan yang diajarkan dan dibutuhkan saat ini tidak lagi sekedar soal akademis dan kualitas intelektual, tapi juga pendidikan moral dan karakter kemanusiaan. Sistem pendidikan seperti yang dimaksud sebenarnya telah jelas diungkap pada Sistem Pendidikan Nasional. Hal ini bermakna bahwa pendidikan merupakan suatu proses/upaya sadar untuk menjadikan manusia menjadi sosok yang lebih baik.

Bahkan Allah telah berfirman dalam A1Quran yang berbunyi :

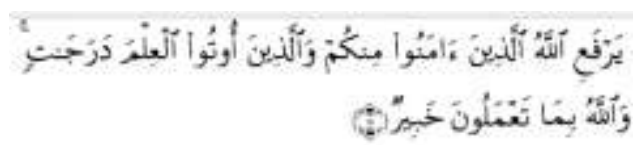

Artinya : Allah akan meninggikan orang yang beriman di antaramu dan orang yang diberi ilmu pengetahuan beberapa derajat (Qs. al-Mujadalah: 11)

Setelah manusia memiliki ilmu pengetahuan, mereka berkewajiban untuk mengamalkan dan mengajarkan ilmu yang sudah mereka peroleh. Hal ini wajib dimiliki oleh guru dalam suatu proses pembelajaran. Pada dasarnya pendidikan mempunyai peranan penting dalam seluruh aspek kehidupan manusia, karena pendidikan berdampak secara langsung terhadap perkembangan pribadi manusia. Pendidikan juga menentukan model manusia seperti apa yang akan dihasilkan. Karena itu, kurikulum sebagai desain pendidikan memiliki kedudukan sentral dalam seluruh kegiatan pendidikan dan turut serta menentukan proses pelaksanaan dan hasil pendidikan.
Majid (2013: 5) menyatakan bahwa pembelajaran adalah kegiatan terencana yang mengkondisikan dan merangsang seseorang agar dapat belajar dengan baik sesuai dengan tujuan pembelajaran. Winkel "Belajar adalah suatu aktivitas mental/psikis selama terjadi interaksi aktif dengan lingkungan, yang menghasilkan perubahan-perubahan dalam pengetahuan, pemahaman, keterampilan, dan sikap-sikap (Hakim, 2009). Peran guru bukan sekedar memberikan informasi, melainkan juga mengarahkan dan memfasilitasi proses belajar agar lebih memadai. Namun, pada kenyataannya kadang peserta didik mengalami kesulitan, seperti kesulitan berkonsentrasi, mengingat, sehingga peserta didik minim aktivitas belajar.

Setiap satuan pendidikan memiliki tujuan kurikulum yang mengacu ke pencapaian tujuan pendidikan nasional, sebagaimana telah ditetapkan dalam UU No.20/2003. Hamalik (2009:24) berpendapat "Kurikulum menye-diakan kesempatan yang luas untuk peserta didik agar mengalami proses pendidikan dan pembelajaran pada semua mata pelajaran".

Salah satu mata pelajaran di Sekolah Dasar adalah mata pelajaran Ilmu Pengetahuan Alam (IPA) atau sering juga disebut dengan sains. Mata pelajaran IPA/sains merupakan mata pelajaran yang dianggap sulit oleh peserta didik, mulai dari sekolah dasar hingga sekolah menengah. Anggapan mayoritas peserta didik yang menyatakan bahwa pelajaran IPA itu sulit benar adanya. Berdasarkan observasi awal pada tanggal 4 Januari 2018 guru mengajar pembelajaran IPA belum menggunakan media pembelajaran, metode yang digunakan pun hanya metode ceramah dan sedikit tanya jawab sehingga pembelajaran menjadi tidak menarik serta membosankan bagi peserta didik. Situasi ini menyebabkan banyak peserta didik yang aktif dengan kesibukannya sendiri seperti berbicara hal yang tidak berhubungan dengan Ilmu 
Pengetahuan Alam yang telah dilaksanakan. Selain itu ada beberapa peserta didik yang menggambar buku, beberapa peserta didik yang bosan, takut, kurang aktif dan kurang berani bertanya serta ragu untuk mengeluarkan pendapatnya. Hal ini ditunjukkan dengan rendahnya persentase aktivitas dalam pembelajaran IPA pada kelas IV, dari 34 peserta didik sekitar $80 \%$ peserta didik tidak aktif selama pembelajaran Ilmu Pengetahuan Alam berlangsung. Hal ini berdampak pada semakin tinggi jenjang pendidikan, aktivitas belajar pada mata pelajaran IPA menjadi semakin rendah terutama dikelas IVB SD Negeri 09 Pontianak Timur. Beberapa istilah yang memiliki kemiripan makna dalam pembelajaran, sehingga seringkali guru merasa bingung untuk membedakannya. Istilah tersebut: (1) pendekatan pembelajaran, (2) strategi pembelajaran, (3) metode pembelajaran, (4) teknik pembe-lajaran, (5) taktik pembelajaran, (6) model pembelajaran (Sudrajat, 2008). Maka dari itu diperlukan penelitian tentang aktivitas belajar pada peserta didik di kelas IV B mata pelajaran IPA SD Negeri 09 Pontianak Timur dengan menggunakan strategi Think Pair Share.

Think Pair Share suatu strategi pembelajaran yang dikembangkan pertama kali oleh Profesor Frank Lyman pada tahun 1981 dan hingga saat ini banyak diadopsi oleh banyak penulis di bidang pembelajaran kooperatif. Strategi TPS memperkenalkan gagasan tentang waktu 'tunggu dan berfikir' (wait or think time) pada interaksi pembelajaran kooperatif yang saat ini menjadi salah satu faktor ampuh dalam meningkatkan respon peserta didik terhadap pertanyaan (Huda, 2016: 206).

Menurut Shoimin (2014: 208) Think Pair Share adalah model pembelajaran kooperatif yang memberi peserta didik waktu untuk berpikir dan merespons serta saling bantu satu sama lain. Menurut Trianto (2007: 61) Think Pair Share merupakan jenis Cooperative learning yang didesain untuk mempengaruhi pola interaksi peserta didik. Arends (dalam Trianto 2007: 61) menyatakan bahwa Think Pair Share merupakan cara efektif untuk membuat variasi suasana pola diskusi kelas.

Manfaat Think Pair Share antara lain: (1) Memungkinkan peserta didik untuk bekerja mandiri dan bekerja sama dengan orang lain. (2)Mengoptimalkan partisipasi peserta didik. Dan (3) Memberi kesempatan peserta didik untuk berpartisipasi kepada orang lain.

Skill yang umumnya dibutuhkan dalam strategi TPS adalah sharing informasi, bertanya, dan meringkas gagasan orang lain, serta paraphrasing.

Think Pair Share (TPS) mengikuti

langkah-langkah berikut ini:

1. Peserta didik ditempatkan dalam kelompokkelompok. (terdiri dari 4 anggota/peserta didik).

2. Guru memberikan tugas pada setiap kelompok.

3. Setiap anggota memikirkan dan mengerjakan tugas sendiri terlebih dahulu.

4. Kelompok membentuk anggotanya secara berpasangan. Setiap pasangan mendiskusikan hasil pengerjaan individu.

5. Kedua pasangan lalu bertemu kembali dalam kelompoknya, dan menshare hasil diskusinya.

Menurut Fadholi (2009:1), kelebihan Think Pair Share antara lain sebagai berikut:

a. Memberi murid waktu lebih untuk berfikir, menjawab dan saling membantu sesama teman.

b. Lebih mudah membentuk kelompoknya.

c. Murid lebih aktif dalam pembelajaran.

d. Murid memiliki kesempatan untuk mempresentasikan hasil diskusinya, sehingga ide menyebar.

e. Memungkinkan peserta didik merumuskan dan mengajukan pertanyaan mengenai materi yang diajarkan.

Menurut Basri 2009: 33 (dalam Mustofa, 2013: 302), kelemahan Think Pair Share antara lain: 
a. Membutuhkan koordinasi bersamaan dari berbagai aktivitas.

b. Memmerlukan perhatian khusus dalam penggunaan ruangan kelas.

c. Menyita waktu pengajaran sebagai akibat dari peralihan dari seluruh kelas ke kelompok kecil dapat.

\section{METODE}

Penilitian ini merupakan penelitian deskriftif kualitatif dan kuantitatif dengan jenis penelitian tindakan kelas. Sanjaya (2009: 44) penelitian tindakan kelas merupakan suatu pengkajian masalah pembelajaran di kelas melalui refleksi diri sebagai upaya memecahkan masalah dengan cara melakukan berbagai tindakan yang terencana dalam situasi nyata serta menganalisis setiap pengaruh dari perlakuan tersebut.

Penelitian ini dilakukan pada Sekolah Dasar Negeri 09 Pontianak Timur pada kelas IV dengan 34 peserta didik. Teknik dan instrumen pengumpulan data berupa teknik observasi dan dokumentasi. Intrumen dalam penelitian ini berupa pedoman observasi dan checklist dokumen.

Adapun tahapan Penelitian Tindakan Kelas (PTK) yang digunakan sebagai berikut:
a. Perencanaan Tindakan (Planning)
b. Pelaksanaan Tindakan (Acting)
c. Pengamatan Tindakan (Observation)
d. Refleksi Terhadap Tindakan (Reflecting).

\section{HASIL DAN PEMBAHASAN}

Setelah melakukan dua siklus penelitian pada pembelajaran IPA menggunakan strategi Think Pair Share yang dilakukan peneliti berkolaborasi dengan guru atau wali kelas IVB.
Diperoleh rekapitulasi aktivitas peserta didik kelas IV yang ditampilkan pada Grafik 1.

Pada gambar 1 menggambar-kan bahwa aktivitas belajar prasiklus sebelum menggunakan strategi Think Pair Share hanya memperoleh skor rerata 58,30\% setelah dilakukan siklus I skor rerata peserta didik menjadi $66,54 \%$ kemudian pada siklus II menjadi $75,73 \%$.

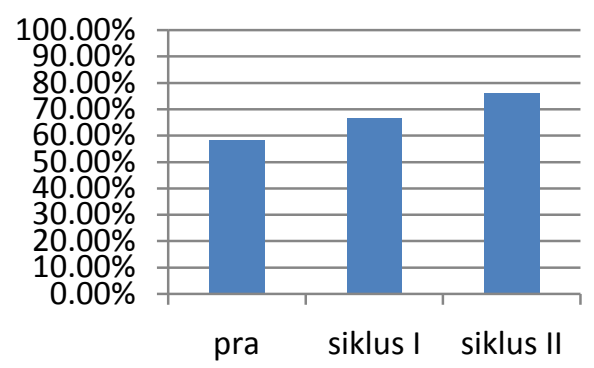

Gambar 1. Rekapitulasi Peningkatan Aktivitas Belajar Kelas IV

Aktivitas belajar yang dilakukan meliputi aktivitas mental, emosional, dan sosial. Penggunaan strategi think pair share memberikan dampak terhadap peningkatan aktifitas belajar yang meliputi 3 aspek.

Kegiatan penelitian dijabarkan sebagai berikut.

1. Dalam perencanaan pembelajaran Ilmu Pengetahuan Alam yang menggunakan strategi Think Pair Share, guru merencanakan beberapa hal, yaitu:

a. Menetapkan jadwal pelaksana-an pembelajaran strategi Think Pair Share.

b. Menetapkan pokok bahasan.

c. Merancang Rencana Pelaksa-naan Pembelajaran (RPP)

d. Menyiapkan materi yang akan dipelajari.

e. Menyiapkan lembar observasi guru.

2. Dalam pelaksanaan pembelajaran Ilmu Pengetahuan

Alam dengan Copyright (C2018, JRPD, ISSN 2615 - 1723 (Print), ISSN 2615 - 1766 (Online) 
menggunakan strategi Think Pair Share, guru melaksanakan beberapa hal, yaitu:

a. Peserta didik ditempatkan dalam kelompok yang terdiri dari 4 peserta didik.

b. Guru memberikan tugas pada setiap kelompok.

c. Setiap anggota memikirkan dan mengerjakan tugas tersebut sendiri terlebih dahulu.

d. Kelompok membentuk anggotanya secara berpasangan. Setiap pasangan mendiskusikan hasil pengerjaan individu.

e. Bertemu kembali dalam kelompoknya untuk menshare hasil diskusi.

f. Guru memberikan kesimpulan.

g. Evaluasi

h. Penutup.

3. Peningkatan aktivitas belajar peserta didik diukur menggunakan panduan observasi aktivitas belajar peserta didik pada setiap siklusnya.

\section{SIMPULAN}

Penelitian ini menunjukkan bahwa strategi Think Pair Share dapat meningkatkan aktivitas belajar peserta didik kelas IV pada mata pelajaran Ilmu Pengetahuan Alam SD Negeri 09 Pontianak Timur dengan hasil peningkatan aktivitas belajar peserta didik sebagai berikut: aktivitas belajar prasiklus sebesar $58,30 \%$; siklus I mengalami peningkatan sebesar $8,24 \%$ menjadi $66,54 \%$; dan siklus 2 mengalami peningkatan sebesar 9,19\% hingga menjadi $75,73 \%$.

Walaupun mengalami peningkatan, tapi masih ada beberapa peserta didik yang belum sepenuhnya aktif dalam mengikut pembelajaran Ilmu Pengetahuan Alam tersebut sehingga peneliti memberikan rekomendasi bagi penelitian lebih lanjut untuk melakukan kombinasi strategi think pair share dengan strategi lain, agar peserta didik lebih aktif dalam proses pembelajaran sehingga pembelajaran akan memberikan dampak langsung dan tidak langsung bagi peserta didik sesuai dengan permendikbud.

\section{DAFTAR PUSTAKA}

Hakim, L. 2009. Perencanaan Pembelajaran Bandung: CV Wacana Prima.

Hamalik, O. 2009. Kurikulum dan Pembelajaran.Jakarta: Bumi Aksara.

Huda, M. 2016. Model-model Pengajaran dan Pembelajaran. Yogyakarta:PT Pustaka Pelajar.

Majid, A. 2013. Strategi pembelajaran. Bandung: PT Remaja Rosdakarya.

Mustofa, A. 2013. Belajar dan Pembelajaran (Kelemahan Strategi TPS). Yogyakarta: Ar-Ruzz Media.

Sanjaya, W. 2009. Penelitian Tindakan Kelas. Jakarta: Kencana Prenada Media Group.

Shoimin, A. 2006. 68 model pembelajaran inovatif dalam kurikulum 2013. Yogyakarta: Ar-Ruzz Media

Sudrajat, A. 2008. Pengertian pendekatan, strategi, metode, teknik, taktik, dan model pembelajaran.

Copyright (C2018, JRPD, ISSN 2615 - 1723 (Print), ISSN 2615 - 1766 (Online) 